\title{
SOCIAL CAPITAL, TRUST AND ENTREPRENEURIAL PRODUCTIVITY*
}

\author{
by \\ VICENTE SALAS-FUMÁS \\ and \\ J. JAVIER SANCHEZ-ASIN ${ }^{\dagger}$ \\ Faculty of Economics and Business, University of Zaragoza
}

\begin{abstract}
With an incomplete panel data from 63 countries over 25 years this paper finds that the average number of employees per entrepreneur increases with the countries' levels of social capital. This evidence is in line with predictions from occupational choice models, where the equilibrium average size of firms increases with lower internal costs of growth, when social capital supported trust reduces these costs facilitating the delegation of decision power in firms. We also find that the influence of social capital in self-employed rates differs if the self-employed have employees or not so entrepreneurs should be treated as a heterogeneous group.
\end{abstract}

\section{INTRODUCTION}

The rate of self-employed is a common measure of countries' level of entrepreneurship (Acs et al., 1994; Blanchflower, 2000). ${ }^{1}$ It is generally accepted that entrepreneurship is an important factor in economic development (Audretsch et al., 2006; Carree and Thurik, 2008; Naudé, 2013), so one would expect higher self-employment rates in more developed countries than in less developed ones. However, since Kuznets (1966), repeated empirical evidence consistently shows just the opposite: the proportion of selfemployed in the working population decreases as the per capita income of countries increases (Gollin, 2008; Gindling and Newhouse, 2014, with data

\footnotetext{
*Manuscript received 29.11.2017; final version received 9.8.2018.

${ }^{\dagger}$ The authors acknowledge financial support from project ECO2013-48496-C4-3-R Spanish Ministry of Economy and Competitiveness, and from the DGA-FSE through the CREVALOR research group. The authors thank the valuable comments and suggestions from the two anonymous reviewers on previous versions of the paper.

${ }^{1} \mathrm{~A}$ distinction is made between behavioral and occupational definitions of entrepreneurs. Behavioral definitions identify entrepreneurs by their actions: starting a new business, introducing innovations, balancing supply and demand (as in the work of Schumpeter and Kirzner). Occupational definitions identify entrepreneurs as self-employed people with decision and residual rights over their work and the work of others, the employees (as in Coase and Lucas). Wennekers et al. (2010) survey research on entrepreneurship as self-employment decisions, while Fritsch and Storey (2014) survey the research that identifies entrepreneurs with the entrepreneurial actions of new firm creations.
} 
from rich and poor countries; OECD, 2016, with data from developed countries only). If the number of entrepreneurs approximately matches the number of firms, countries with lower self-employment rates will be countries with a higher average size of firms. The negative association between self-employment rates and per capita income is then consistent with other evidence generating increasing interest: the positive association between the average size of firms and economic development (Bento and Restuccia, 2015; Hopenhayn, 2016).

This paper provides an economic explanation, supported with empirical evidence, of the observed cross-countries differences in self-employment rates and in average firm sizes. The explanation is based on Coase's (1937, page 388) definition of the entrepreneur ' $[. .$.$] the person or persons who, in$ a competitive system, take the place of the price mechanism in the direction of resources', and on the occupational choice theory that explains the number of entrepreneurs in the economy as a market equilibrium (Lucas, 1978). Occupational choice models predict that the equilibrium number of entrepreneurs will be lower and the average productivity per entrepreneur (employees per entrepreneur) higher in economies with low organizational size diseconomies (low marginal management costs) than in economies with high organizational size diseconomies (Rosen, 1982). There is also theory (Aghion and Tirole, 1997; Aghion et al., 2014) supported by empirical evidence (Bloom et al., 2012; Gur and Bjornskov, 2017) showing that trusts favours effective decentralization of decisions in organizations, reducing management cost and consequently reducing the internal costs of growth. Therefore, trust as facilitator of decentralized organizations creates a link between social capital as determinant of trust (Coleman, 1990; Adler and Kwon, 2002; Glaeser et al., 2002; Kwon and Adler, 2014) and the number and productivity of entrepreneurs in the economy.

A better understanding of why countries differ in the number of the self-employed is important for further clarification of the relationship between entrepreneurship and economic development. The population of self-employed includes those self-employed who do not hire employees, the solo self-employed, and those self-employed who hire employees, the employers. Since only the employers properly qualify as Coasian entrepreneurs, i.e. as directors of the work of employees, the explanation of the number of employers can differ from the explanation of the number of solo selfemployed. The empirical evidence presented later also justifies the recognition of the self-employed as a heterogeneous group: with data from 62 countries over 25 years, the proportion of employers in the total occupied population is independent of the level of economic development, while the proportion of solo self-employed is negatively and significantly associated with economic development. The observed negative correlation between rates of all self-employed and GDP per capita is then attributed to the negative association between GDP per capita and rates of solo self-employed. 
The literature on entrepreneurship and economic development has recognized the importance of considering entrepreneurship as a heterogeneous phenomenon, concluding that not all entrepreneurs contribute equally to economic development (Lerner and Schoar, 2010; Gindling and Newhouse, 2014). We claim in this paper that the number and composition of entrepreneurs as self-employed are endogenously determined, together with the level of total economic output. Therefore, entrepreneurship does not 'cause' economic development, but rather, entrepreneurship and economic development both respond to similar exogenous factors.

Data on the number of individuals in the various occupational groups, employees, employers and solo self-employed, are taken from the International Labour Organization (ILO) database for all countries and years in which data are available. Data on social capital come from two sources, the IVIE social capital index, SCI, available for a long list of countries and years (Fernández de Guevara et al., 2015), from the World Values Survey (WVS, 2014), and from the European Social Survey (ESS, 2014). The SCI measure is based on the economic approach of Glaeser et al. (2002) to the measurement of social capital. The data from the WVS and EES are direct measures of generalized trust in the countries covered by the surveys. The SCI has the advantage of being a panel data that can be matched with the panel data on relative sizes of occupational groups, but the evidence on how well the index correlates with direct measures of trust is scarce (Pastor and Tortosa-Ausina, 2008). The WVS and EES survey data have the advantage that they provide a direct measure of trust, but are available only for a limited number of countries and years. Our empirical results support the main hypothesis of the paper with both sources, the IVIE and the WVS and EES measures of social capital and trust.

Blau (1987), and Evans and Leighton (1989) are early papers on the determinants of the time evolution of self-employment rates in the USA. Acs et al. (1994), with data from the same ILO database used in this paper, focus their attention on cross-country differences in self-employed rates, as does Blanchflower (2000) with data from OECD countries. Fritsch et al. (2015) investigate the possible reasons behind the recent strong increase in selfemployment in Germany. The research interests of all these papers are more focused on explaining possible changes in entrepreneurship trends over time, rather than in explaining cross-country differences in entrepreneurship. They all conclude that variations in self-employment rates respond more to changes in the economic environment (shift of activity from manufacturing to services, changes in the distribution of population in age cohorts, business cycle, taxation policies, etc.) than to changes in the inclination of individuals to be self-employed. Our paper contributes to this empirical literature with a theoretical explanation of differences in selfemployment rates grounded in the theory of occupational choice, and with 
a yet-unexplored connection between the equilibrium number of entrepreneurs and the internal organization of firms.

The rest of the paper is organized as follows. Section 1 presents the theoretical roots of the hypotheses to be tested, together with the connection of our work to the related literature. Section 2 presents the data base and the formulation of the empirical model. Section 3 presents the empirical results on the relationship between social capital and entrepreneurs' rates and productivity. The conclusion summarizes the main results of the paper.

\section{Theory and Related Literature}

\subsection{Sizes of occupational Groups and management Costs Diseconomies}

The basic theory on the determinants of the number of entrepreneurs as solo self-employed in an economy is based on Lucas (1978), on the equilibrium distribution of firm sizes from the occupational choice of individuals with different levels of entrepreneurial skill. The original work, that allows for only two occupational groups, employers and employees, is extended in Salas-Fumás et al. (2014) and Medrano-Adán et al. (2015) to account for the solo self-employed as a third occupational choice, and for management costs (Coase, 1937; Rosen, 1982). In this section, we briefly describe the model and main results, and explain the relationship between the predictions of the model and other related results in the literature on social capital-trust and entrepreneurship.

In the occupational choice models, individuals with different skills, general or entrepreneurial, choose to work as entrepreneur or as employee, depending on the income earned in each occupation (a function of skills). Production uses three inputs, labour from direct employees, capital services and entrepreneurial services. The entrepreneurial input enters the production function in two ways, as part of the total factor productivity component of the production function and as a management input that supervises the execution of strategic decisions. The production function that captures the assumptions of the occupational choice theory is formulated as follows (Rosen, 1982; Medrano-Adán et al., 2015):

$$
Y=g(e) e^{\beta}[F(K, L)]^{1-\beta}
$$

Where $e$ is the level of skill of the entrepreneur, $K$ is the capital input and $L$ is the direct labour input. The term $g(e)$, increasing in $e$, is the contribution of the entrepreneur input to the total factor productivity of the production unit from the quality of the strategic decisions (higher quality increases the productivity of all inputs directed by the entrepreneur). The function $F(K, L)$ is increasing and linear homogeneous in capital and labour (constant returns to scale). The parameter $0 \leq \beta \leq 1$ is the degree of organizational size diseconomies resulting from the cost of the entrepreneur 
directing the allocation of the two resource inputs, labour and capital, i.e. diseconomies of size in the management costs, in the terminology of Coase (1937). This is also the key parameter in our analysis of the number of entrepreneurs and social capital. A value of the parameter $\beta$ lower than one implies that the term $[F(K, L)]^{1-\beta}$ has decreasing returns to scale in labour and capital. Since the skills of the entrepreneur $e$ are fixed, when the entrepreneur chooses $K$ and $L$ that maximize profits for given input and output prices, the output and profits are positive and increasing with skills $e$. Individuals working as employees only earn the market-determined salary (Medrano-Adán et al., 2015).

In the market equilibrium from occupational choices, no individual wants to change occupation and the supply of employees is equal to the demand from entrepreneurs-employers. In this solution, highly skilled individuals work as entrepreneurs-employers and less skilled ones as employees. The average productivity of entrepreneurs is measured by the average span of control, i.e. the number of employees per entrepreneur. The fewer the number of entrepreneurs the higher the average span of control and the higher the average size of firms when number of entrepreneurs and number of firms coincide. Comparative static analysis in the market equilibrium gives the result that higher value of parameter $\beta$, i.e. higher organizational size diseconomies, results in more entrepreneurs and smaller average span of control.

The extension of the model to three occupational groups-employees, entrepreneurs-employers and entrepreneurs solo self-employed - can give different results depending on the additional assumptions around the model. Salas-Fumás et al. (2014) show that, in the equilibrium, individuals who voluntarily choose solo self-employment have skills intermediate between those choosing to work as employees and those working as employers. The comparative static analysis shows now that higher $\beta$ implies a higher number of both solo self-employed and employers, in the new equilibrium. Medrano-Adán et al. (2015) solve for the occupational equilibrium in an economy with three occupational groups and a minimum wage. The market equilibrium now includes two groups of solo self-employed, those who voluntarily choose solo self-employment, with relatively high skills and income, and those who involuntarily become solo self-employed, with skills lower than the minimum skills at which a person finds a job as employee and earns the minimum wage. ${ }^{2}$ In this equilibrium, the comparative static exercise shows that the number of

\footnotetext{
${ }^{2}$ The minimum wage is one of several possible reasons for the existence of the involuntary solo self-employed. The key point is that there can be legal (minimum wage), economic (tax evasion), and technical (minimum skills required for use of certain technologies) factors determining the number of involuntary solo self-employed. The model confirms that the contribution to total output of the voluntary solo self-employed, with middle-to-high levels of skill and income, is greater than the contribution from low-skilled and low-income involuntary self-employed individuals.
} 
voluntary solo self-employed individuals increases with $\beta$, while the involuntary solo self-employed decreases with $\beta$.

\subsection{Management cost, Size Diseconomies and Social Capital}

The next hypothesis to explain cross-country differences in the relative sizes of occupational groups and the average span of control is that differences in social capital, as a support of generalized trust, imply differences in the value of the parameter $\beta$, the degree of organizational size diseconomies from management costs. Specifically, the hypothesis is that, in environments of higher social capital and generalized trust, management systems and organizational designs will involve greater decentralization of decisions to lower levels of the hierarchy, saving in intensity in the use of inputs from the management-supervision function of the entrepreneur. Therefore, production in countries with higher social capital and trust will take place in organizations whose management technology will have lower values of parameter $\beta$ than the management technologies dominating in countries with lower social capital and lower generalized trust.

Aghion and Tirole (1997) and Aghion et al. (2014) formally prove that optimal decentralization of decision-making in hierarchical organizations is greater in high trust environments because collaboration among specialists will take place in conditions of higher goal congruence. Gur and Bjornskov (2017) find a strong positive association between trust and delegation in cross-country data, but only for developed countries. Bloom et al. (2012) find that multinational companies with headquarters in high-trust countries delegate more decisions to managers of their foreign subsidiaries than multinationals with headquarters in low-trust countries, and attribute this result to the theoretical results of Aghion and Tirole (1997). ${ }^{3}$ La Porta et al. (1997) report empirical evidence of the positive association between the level of generalized trust in a country, and the relative importance of large firms in this economy, which can also be interpreted as evidence that trust lowers the agency costs of delegation and consequently it lowers the management costs of firms' growth. Kummar et al. (2002) explain differences in firm size across-countries and include institutional variables, such as protection of property rights, as potential determinants of cross-country differences in the sizes of firms. Since generalized trust reduces the cost of contracting because trust supports the use of implicit contracts to govern

${ }^{3}$ Bloom et al. (2012) develop a theory section explaining the equilibrium number of entrepreneurs from occupational choices, only employees and entrepreneurs with employees, when managers help to solve operational problems (Garicano, 2000; Garicano and Rossi-Hansberg, 2006), rather than in supervising the execution of strategic decisions (Rosen, 1982), assumed here. They predict an effect of higher trust on the equilibrium number of managers similar to what we predict here for employers. 
economic transactions (Kreps, 1990; Williamson, 1993; Glaeser et al., 2002), in environments of higher trust the protection of property rights can be easily done by implicit contracts, which again lowers the costs of growth. Cingano and Pinotti (2016) document that trust-based delegation makes firms more efficient and contributes to a shift in the size distribution from smaller to larger size classes.

All these theoretical and empirical results lead us to hypothesize that diseconomies of size from management costs, the value of parameter $\beta$ in the model, will decrease with the level of social capital as support of generalized trust in the economy. Then, taking into account the predictions from occupational choice models on how different values of the parameter $\beta$ affect the relative size of the occupational groups in the equilibrium, we predict that: (i) countries' social capital will be negatively associated with countries' rate of entrepreneur-employers, and positively associated with countries' average span of control; (ii) the relationship between social capital and the rate of solo self-employed is undetermined: a positive (negative) association will indicate that the effect of differences in social capital on the rate of voluntary solo self-employed is higher (lower) than the effect of differences in the rate of involuntary solo self-employed.

We notice that these hypotheses, although related to the literature on trust, delegation, and the size of firms, incorporate important differences. First, our unit of analysis is not the firm as a legal entity, but the physical person of the entrepreneur. Management costs result from the coordination and supervision function of the entrepreneur and are independent of constituting a legally independent entity, a corporation, or not. If the number of employers in a country were the same as the number of legally independent firms, then the average size of firms and average span of control would coincide, but this is not necessarily the case and, often, entrepreneurs conduct business with several legal entities (Salas-Fumás and Sanchez-Asin, 2013a). Average span of control is a variable more closely related to the predictions of the theory than the average size of firms, because the boundaries of firms that matter in the context of the model are those determined by the unit of command, not by the property rights over the assets of the legal entity. Second, our hypotheses come from economy-wide equilibrium solutions so they do not apply to the size or growth of individual firms; we formulate and test hypothesis with country level data on the respective sizes of occupational groups. Finally, we distinguish between those self-employed who do, and those who do not, hire employees, a distinction not made in the referenced literature. ${ }^{4}$

${ }^{4}$ The paper focuses on the relationship between social capital and the number and productivity of entrepreneurs in the economy. It leaves out the detailed reference to research on how social capital and trust affect economic development (Knack and Keefer, 1997; Zak and Knack, 2001; Alesina and La Ferrara, 2002; Pérez García et al., 2006; Akçomak and ter Weel, 2009; Peiró-Palomino and Tortosa-Ausina, 2015). 


\subsection{Entrepreneurship and Social Capital}

A large body of entrepreneurship research has investigated the link between social capital and entrepreneurship (Westlund and Bolton, 2003; Gedajlovic et al., 2013; McKeever et al., 2014). The most common conclusion of this research is that countries and regions with higher levels of social capital are also regions with higher rates of new firm creation (Westlund and Adam, 2010; Bahmani et al., 2012; Estrin et al., 2013; Westlund et al., 2014) and regions with relatively more individuals involved in creating new firms (Bahmani et al., 2012).

Kwon and Arenius (2010), with GEM data from several countries, provide evidence that trust supports entrepreneurship because in environments of high trust there will be more business opportunities and it will be easier for the new ventures finding external finance. Social capital and trust broadly contribute to creating a fertile ground for the flourishing of entrepreneurial activities. It facilitates information diffusion and technology adoption, and eases access to labour and capital inputs, including informal finance, especially in the start-up phase (Baron et al., 2010; Bosma et al., 2004; Guiso et al., 2004; Bramoullé and Kranton, 2007; Michelacci and Silva, 2007; Alexy et al., 2012).

The literature on entrepreneurship predicts a positive association between the countries' social capital and entrepreneurial activity levels because social capital works as a 'lubricant' (Arrow, 1974) that facilitates the access to information and resources, especially to new entrepreneurs. In this paper, we predict that higher social capital will be associated with fewer and more productive entrepreneurs. One way to explain the different predictions is by the fact that the literature on entrepreneurship adopts the view of the entrepreneur proposed by Schumpeter, while in this paper we adopt the view of the entrepreneur proposed by Coase. For Schumpeter the entrepreneur and entrepreneurial activities (entry of new firms, exit of existing ones and changes in occupations...) are synonymous of disequilibrium and creative destruction. In contrast, the Coasian entrepreneur contributes to social order and coordination. In fact, occupational choice models predict the number of entrepreneurs in the market equilibrium but say nothing about the transition between equilibriums. The exception is Hopenhayn (2016) who models a dynamic process of entry and exit of firms where entrepreneurs learn by experience about their entrepreneurial skills that converges to the static occupational choice equilibrium. Then, an economy can be considered highly entrepreneurial because it shows a high rate of entry and exit of entrepreneurs starting and closing businesses, and at the same time with a relatively small number of entrepreneurs (capital stock) in the stationary equilibrium.

Finally, the view on how social capital contributes to wealth creation in the entrepreneurship literature does not make a clear distinction between 
social capital as a 'bridging' (Bourdieu, 1980; Burt, 1982) or as a 'bonding' (Coleman, 1988; Putnam, 1995) asset, i.e. between internal and external social capital (Adler and Kwon, 2002). Bridging and external capital is a private asset that benefits society through the private benefits of individuals or groups that own the asset, most often facilitating them the access to other private external resources, including those needed to become an entrepreneur. Bonding or internal social capital is a public good, freely accessible to all members of the community, which facilitates collaboration and exchanges (it lubricates the economic system in words of Arrow). Our paper is grounded in social capital as a public good, and its effects on economic efficiency are ultimately measured in terms of contribution to the productivity of the whole economy, not as a private gain.

\section{Data AND eConometric MOdels}

\subsection{Data Sources and Variables}

There are three endogenous or dependent variables, the relative sizes of occupational groups of employers and solo self-employed, and the average span of control of employers, each measured for a country and year. The main explanatory variable is the social capital and trust, also of a country and year.

The data on employers, solo self-employed and employees for each country and year come from the statistics published by the ILO in the ILO's central statistics database ILOSTAT (2013). The number of countries for which data are available varies from year to year; our final database covers the period 1987-2011 (25 years) and up to 63 countries (incomplete panel data). The time period is conditioned by the availability of data on social capital. The ILO database contains information, for each country and year reported, on the number of individuals who are self-employed with employees (employers), the number of self-employed without employees (solo self-employed) and the number of employees. With this information, we define and measure the following dependent variables of the empirical model:

$S E_{i t}=$ Share of self-employed with employees: the ratio between the number of employers and all occupied individuals (employers, solo selfemployed and employees) of country $i$ in year $t$.

$S S E_{i t}=$ Share of self-employed without employees (solo self-employed): the ratio between the number of self-employed without employees and all occupied individuals (employers, solo self-employed and employees) of country $i$ in year $t$.

$S o C_{i t}=$ Average span of control: the ratio between the number of employees and the number of employers of country $i$ in year $t$. This variable is interpreted as an indicator of the average productivity of entrepreneurs-employers. 
In an economy with only employers and employees, the variables share of employers, $S E$ and average span of control, $S o C$, would be mutually determined $(S o C=(1-S E) / S E)$. With the existence of solo self-employed this is no longer the case because the solo self-employed enter into the calculation of the share of employers (denominator with all occupied individuals) but not in the calculation of the span of control.

The data on the main explanatory variable, the social capital of countries in a given year, come from the database elaborated by the Spanish Institute of Economic Research, IVIE. Social capital is expressed as an index, $S C I_{i t}$, social capital index for country $i$ in year $t$, normalized so that the value for the year 2000 is set equal to 100. From the years 1987-2005, the data source is the web site https://www.ivie.es/es_ES/bases-de-datos/ diferencias-economicas-y-sociales-de-los-territorios/capital-social/, and for the years 2006-2011, the data on social capital come from the book of Fernández de Guevara et al. (2015). The continuity of the two data sources is assured because the same research team, using the same methodology, elaborates both databases. The methodology used in the calculation of the IVE social capital index follows the economic approach proposed by Glaeser et al. (2002). It is explained in detail in Pérez García et al. (2006), according to which, social capital is a stock that varies year by year by the net flow resulting from new investment in year $t$, and depreciation of the existing stock also in year $t$. The complication lies in the search for the right proxy variables to calculate the flow of new investment, and the depreciation rate. In the Appendix we provide more detailed explanation of the theoretical and methodological foundations of the IVIE social capital measure.

In the literature, it is common to find variables that are proposed as proxy measures of social capital in support of trust, such as associative density (Putnam, 1995), electoral turnout and blood donation (Guiso et al., 2004) and the prevalence rate of social entrepreneurs (Estrin et al., 2013), where social capital is synonymous of level of citizenship. The IVIE-SCI belongs to the class of measures that can be used as being indicative of the level of trust in a country, in particular the trust resulting from calculations by rational individuals of the benefits and costs of trusting others. Pastor and Tortosa-Ausina (2008) document a positive association between the IVIE-SCI, as social capital that supports trust, and direct measures of individual perceptions of generalized trust, such as those obtained from the WVS survey. The IVIE-SCI has been used in other research studies (Pastor and Tortosa-Ausina, 2008; Miguélez et al., 2011; Salas-Fumás and SanchezAsin, 2013b; Peiró-Palomino and Tortosa-Ausina, 2015).

The advantage of IVIE-SCI over other measures of generalized trust is the availability of data from a long list of countries and many years of time. Limitations may arise from the questioning of the proxy variables used to estimate the stock of social capital with measures of the flow of new investments and depreciations. We then complement the main results of our 
analysis with a test of the hypothesis of the paper using the measure of trust provided by the World Values Survey (WVS, 2014) and the European Social Survey (ESS, 2014).

As advanced in the introduction, prior research has explained differences in self-employed rates across countries using other explanatory variables, different from social capital and trust. We then add to the list of explanatory variables of our empirical model, control variables to account for other factors underlying differences in the size of occupational groups that could be correlated with the SCI. The variable unemployment rate of country $i$ in year $t, U R_{i t}$, capture the position of the country in the business cycle, together with possible structural differences in the functioning of labour markets across countries (regulations, unemployment insurance). The variable $U R$ is calculated with data from the ILO database as the number of unemployed divided by the active population (occupied plus unemployed persons).

The second control variable is the proportion of occupied individuals in agriculture for country $i$ in year $t, A G_{i t}$. This variable captures differences in productive specialization across countries, which may determine differences in production technologies and in interpersonal relationships (in agriculture, it is more common to find a family business whose members will trust each other for reasons other than calculative trust). The variable $A G$ is measured with data from World Bank statistics. The third control variable is the size of country $i$ in year $t$, measured by the country gross domestic product $G D P_{i t}$. This variable controls for differences in specialization opportunities due to the incremental costs firms face when exporting to other countries, as well as for differences in competition intensity (the larger number of firms in the market makes collusion practices more difficult). The size of the national market is measured by GDP at constant 2005 \$US, taken from the World Bank database.

Occupational choice models predict that occupational rates and output per occupied individual (proxy of per capita income) are jointly determined in the market equilibrium. Therefore, variables such as per capita income and the like are endogenous variables that should be excluded as determinants of self-employment shares. However, there may be unobserved determinants of the decision to delegate decision power in organizations that operate differently above a certain threshold of income (e.g. the education level of the population), which are worth controlling for. With this purpose in mind, we include as a forth control variable the dummy variable Rich that takes the value of 1 for countries with per capita income above the income of the median country in year $t$, and 0 otherwise.

Finally, we control with time and country dummy variables for unobserved common to all countries time varying effects and for idiosyncratic differences among countries, respectively. The time dummy variables account, among other things, for differences in the number of countries for 
which information is available from year to year. The country fixed effects control for omitted variables that can have an effect on permanent differences in self-employment rates across countries, and at the same time be correlated with the $S C I$; e.g. culture and tradition, quality of formal institutions or size of the government budget.

\subsection{Econometric Model}

Occupational choice models predict that the relative sizes of each occupational group will converge to market equilibrium values. We model the determinants of the occupational shares as if the observed values of the dependent variables were realizations of the variable along a time path of adjustments towards market equilibrium values. Let $Y^{*}$ be the equilibrium value of the variable (e.g. the share of employers, $S E_{i t}$ ) and let $Y_{t}$ be the current value of the variable in year $t$. Then, we postulate the partial adjustment process as follows,

$$
Y_{t}-Y_{t-1}=\delta\left(Y^{*}-Y_{t-1}\right)
$$

where $\delta$ is a positive parameter that depends on the costs of adjustment (non-observable and to be estimated). The equilibrium value $Y^{*}$ is assumed to be a function of the social capital index (SCI) and of the control variables $(c v): Y^{*}(\mathrm{SCI}, c v)$. Substituting in [1] and arranging the terms:

$$
Y_{t}=(1-\delta) Y_{t-1}+\delta Y^{*}(\mathrm{SCI}, c v)
$$

The long-term value of the dependent variable $Y^{*}()$ is expressed as a linear function of the SCI and of the control variables, all lagged one time period to avoid simultaneity in the determination of their respective values. The SCI and the size of the market variables are introduced into the model in $\operatorname{logs}(L n)$ to account for possible decreasing effects in the dependent variable of changes in the value of the explanatory variable going from low to high values. The complete empirical model is then the following:

$$
\begin{aligned}
Y_{i t}= & \eta_{i}+\alpha_{1} Y_{i t-1}+\alpha_{2} L_{n S C I_{i t-1}}+\alpha_{3} U R_{i t-1}+\alpha_{4} A G_{i t-1}+\alpha_{5} L n G D P_{i t-1} \\
& +\alpha_{6} \text { Rich }_{t}+\alpha_{7} D_{t}+\varepsilon_{i t}
\end{aligned}
$$

Where $\eta_{i}$ is a dummy variable that takes the value 1 if the observation belongs to country $i$, and 0 otherwise, $D_{t}$ is a time dummy variable and $\varepsilon_{i t}$ is the random error term.

Equation (3) is estimated for the three dependent variables defined in Section 2.1. The variables share of employers and share of solo self-employed are expressed in their logistic transformation, $\operatorname{Ln}\left(S E_{i t} /\left(1-S E_{i t}\right)\right)$ and $\operatorname{Ln}\left(S S E_{i t} /\left(1-S S E_{i t}\right)\right)$ respectively, so their values can go from minus to plus 


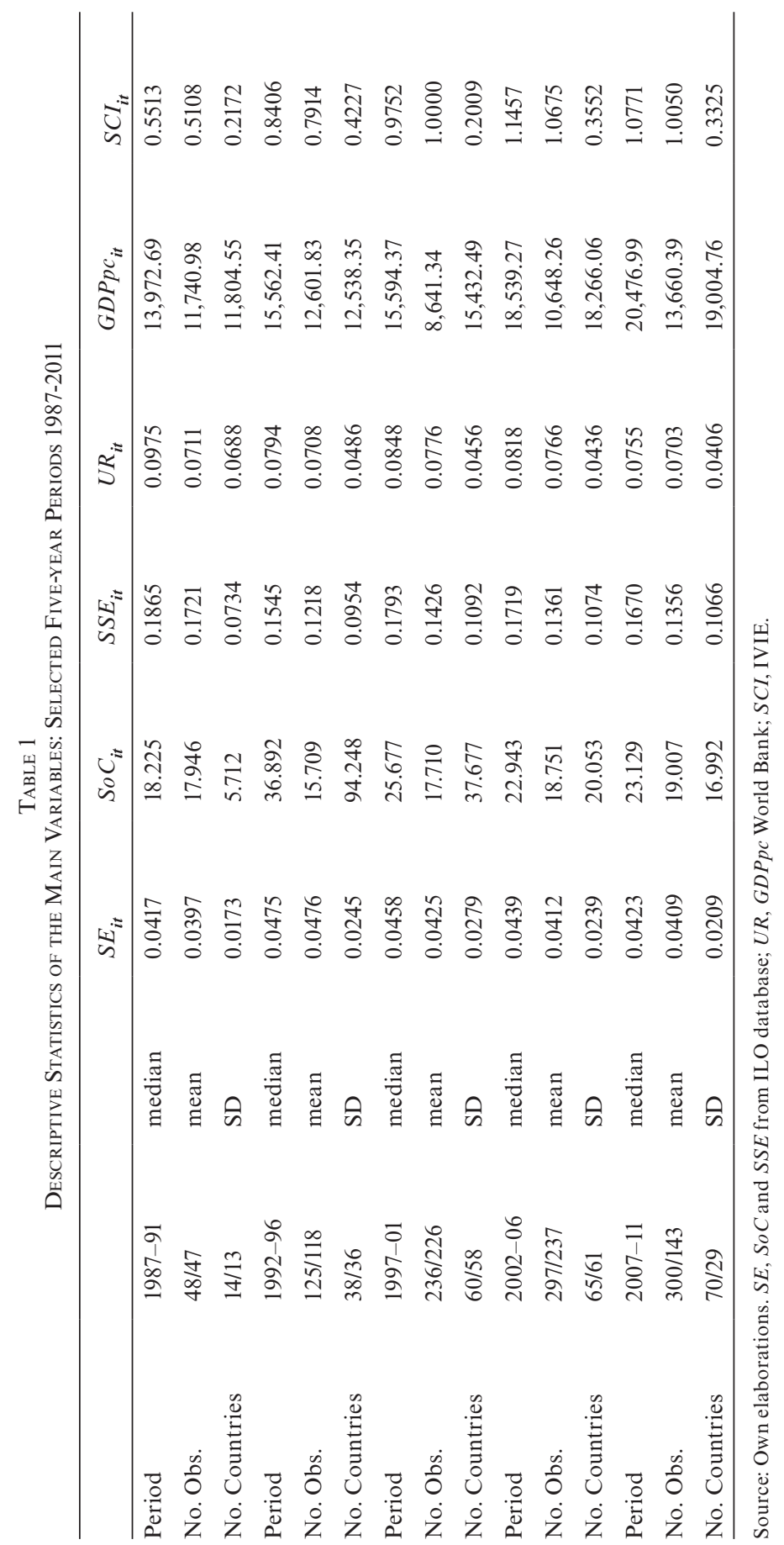

(c) 2018 The University of Manchester and John Wiley \& Sons Ltd 


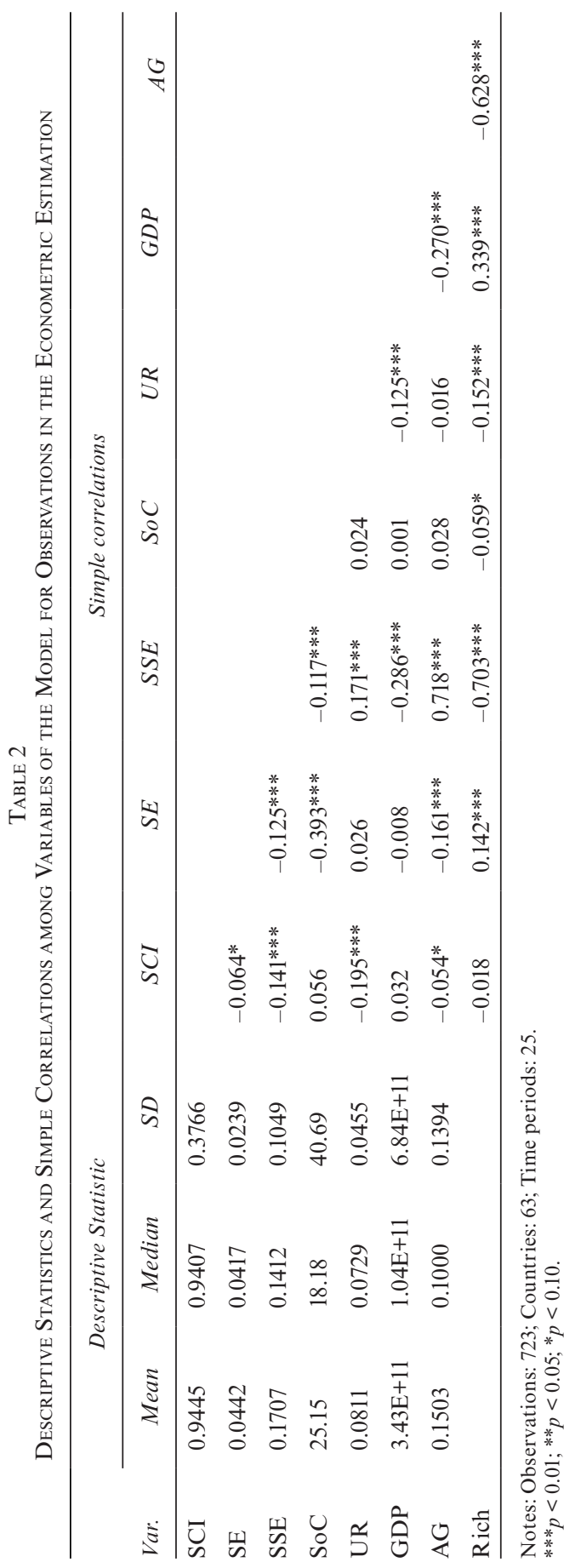

(C) 2018 The University of Manchester and John Wiley \& Sons Ltd 
infinity. The average span of control is measured in logs, $\operatorname{Ln}\left(\mathrm{SoC}_{i t}\right)$. For consistency tests, we also estimate the long-term or stationary version of model [3], $Y^{*}(\mathrm{SCI}, c v)$, where the lagged dependent variable is excluded from the explanatory variables. From the stationary equilibrium of the dynamic equation [3], the estimated coefficients of the long-term equilibrium model $Y^{*}(\mathrm{SCI}, c v)$ are equal to those estimated from model [3] divided by $\left(1-\alpha_{1}\right)=\delta$.

\section{EMpiricAl Results}

\subsection{Descriptive Statistics and Preliminary Analysis}

Our database is an incomplete panel data covering up to 63 countries for the 25-year period between 1987 and 2011, for a total of 728 country-year observations and a minimum of eight countries per year. Table 1 presents the descriptive statistics for the main variables of the model, number of countries, mean, median and standard deviation (SD) of the main selected variables: share of employers, $S E$, span of control, $S o C$, share of solo self-employed, $S S E$, unemployment rate, $U R$, Gross Domestic Product per capita, $G D P_{p c}$ and the Social Capital Index, SCI. The first number in the row 'No. Obs.' ('No. Countries') indicates the number of observations (countries) for which information on the values of the variables $S E, S o C$ and $S S E$ is available. The second number corresponds to the number of observations (countries) for which information on $S C I$ is available. The statistics of each variable are calculated with all the observations available.

The number of country-year observations increases over time. The median of $S E$, share of employers, stays between 4 per cent and 5 per cent in all periods, while $S S E$, share of solo self-employed, stays around 17 per cent. The average unemployment rate, average $U R$ is close to 8 per cent stable over time. The median of the number of employees per employer $(\mathrm{SoC})$ stays between 18 and 37. The median $G D P_{p c}$ rises over time from $\$ 14,000$ at the outset to $\$ 20,500$ by the end of the period. The value of $S C I$ is normalized, assigning a value of 1 to the original variable in year 2000, and adjusting accordingly. The median $S C I$ in each sub-period shows a positive trend until 2006. In the final sub-period, the median of the observations decreases, probably due to the economic crisis.

Table 2 presents the descriptive information from the values of the variables used in the estimation of our econometric models. The mean, median and SD of the variables are consistent with those of Table 1. Notice that $S C I$ is negatively correlated with self-employment shares ( $S E$ and $S S E$ ), unemployment rate $(U R)$ and with the proportion of employment in agriculture $(A G)$, but uncorrelated with the span of control $(S o C)$, the size of the country $(G D P)$ and the dummy variable (Rich). The correlation between $S E$ and $S S E$ is negative but small; $S E$ is negatively correlated with the proportion of agricultural workers and positively with Rich. On the other hand, SSE is positively associated with $U R$ and $A G$, but negatively with the size $(G D P)$ 
1a:Employers

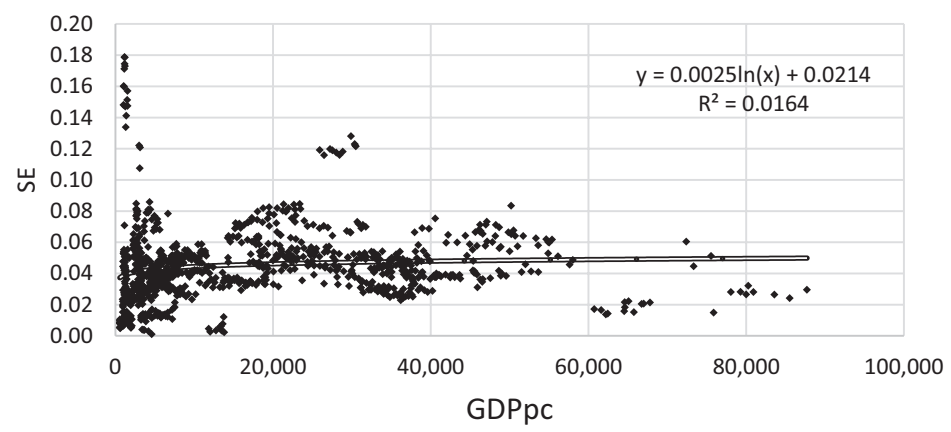

1b: Solo self-employed

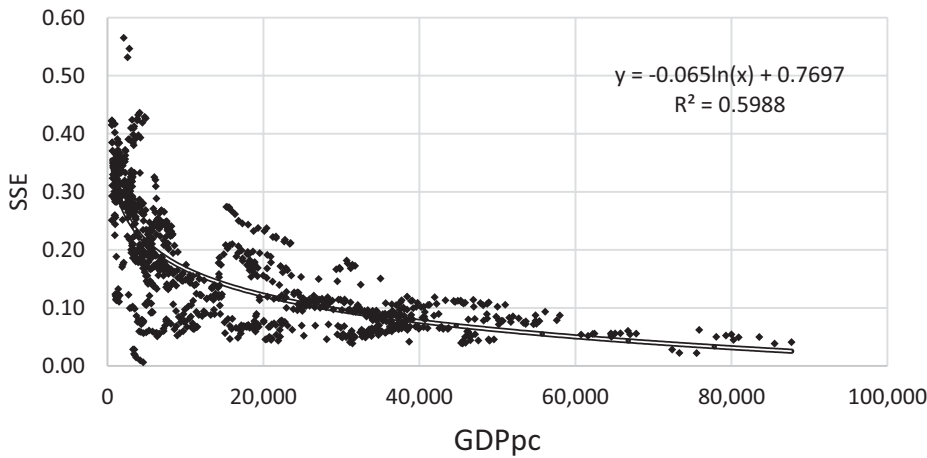

1c: All self-employed

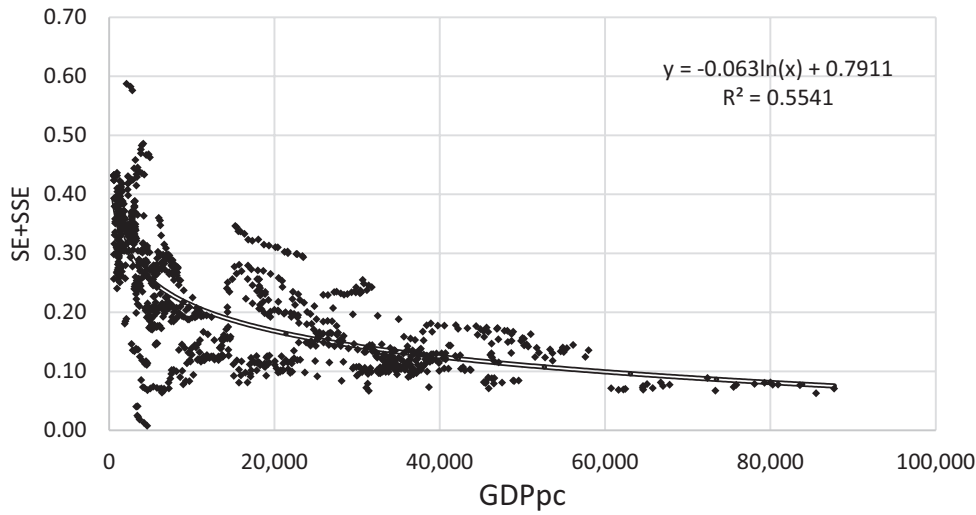

FIG. 1. GDP pc and Self-empl oyment Shar es: All Observations 1987-2011.

and wealth (Rich) of countries. The variables Rich and GDP are positively correlated, while $A G$ and Rich are negatively correlated. 
With the exception of the correlation between Rich and the proportion of agricultural workers, close to -0.7 , the rest of simple correlations in Table 2 are relatively small in absolute values. The highest correlation in absolute value is that between $S C I$ and the unemployment rate, -0.19 , probably because the unemployment rate enters in the IVIE's calculation of social capital. However, the value of the correlation is sufficiently low for not having to care about multicollinearity problems. Another remarkable result is the quite small correlation (significant only at $p<10$ per cent) between $S E$ and $S S E$, and the different sign of the correlation between Rich and $S E$ (positive) and $S S E$ (negative). These results confirm, once again, the importance of treating the self-employed as a heterogeneous group.

The opposite signs in the association between employers $(S E)$ and solo self-employed $(S S E)$ rates and per-capita income are more visible in Fig. 1. Other papers have presented a plot similar to Fig. 1(c), with the negative association between self-employment shares, as a homogeneous group $(S E+S S E)$, and per-capita income (Gollin, 2008; Wennekers et al., 2010), but the Fig. 1(a) and (c) on per capita income and separate self-employment rates for employers and for solo self-employed, are new in the literature. Table 3 shows a summary of the estimated coefficients of the explanatory variable GDP per capita in logs, $\operatorname{Ln}\left(G D P_{p c}\right)$, in simple regressions with two dependent variables: rate of employers, $S E$, and rate of solo self-employed, $S S E$, both for selected five-year sample periods, in the time interval 19872011. In all estimations, the rate of employers $(S E)$ is independent of the level of economic development (every estimated coefficients of GDP per capita are close to zero and not statistically significant). On the other hand, the estimated semi-elasticity of the rate of solo self-employed (SSE) with respect to GDP per capita is always negative, statistically significant and with a value close to $-0,065$ in all estimations. The relationship between self-employment rates and economic development, measured in terms of per capita income, appears to be very stable over time.

TABLE 3

Estimated Coefficients of the Variable Ln (GDpc) for Dependent Variables SE and SSE: Selected Five-Year Periods 1987-2011

\begin{tabular}{lcccc}
\hline Period & No. Observations & No. Countries & $\boldsymbol{S E}$ & $\boldsymbol{S S E}_{\mathbf{i}}$ \\
\hline $1987-91$ & 48 & 14 & 0.0005 & $-0.0600^{* * *}$ \\
$1992-96$ & 123 & 37 & 0.0107 & $-0.0635^{* * *}$ \\
$1997-01$ & 231 & 60 & 0.0037 & $-0.0653^{* * *}$ \\
$2002-06$ & 294 & 65 & 0.0011 & $-0.0656^{* * * *}$ \\
$2007-11$ & 295 & 68 & 0.0008 & $-0.0671^{* * *}$ \\
\hline
\end{tabular}

Source: Own elaborations. SE, and SSE, ILO database; GDPpc World Bank.

$* * * p<1$ per cent.

(C) 2018 The University of Manchester and John Wiley \& Sons Ltd 
2a: Employers

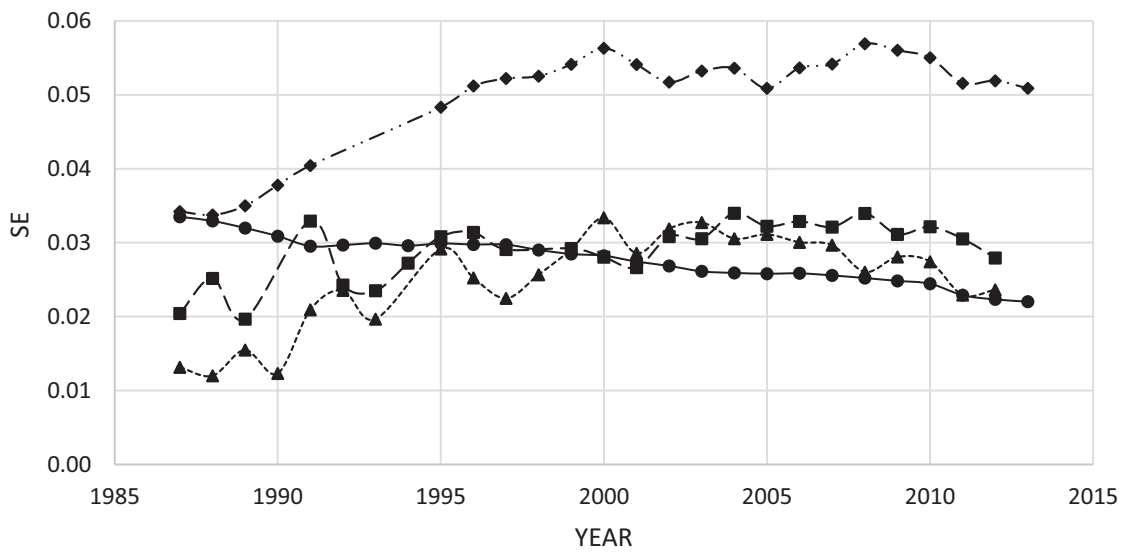

---- Thailand $\quad-$ - Panama $\quad \bullet$ Spain $\longrightarrow$ Japan

2b: Solo Self-employed rates

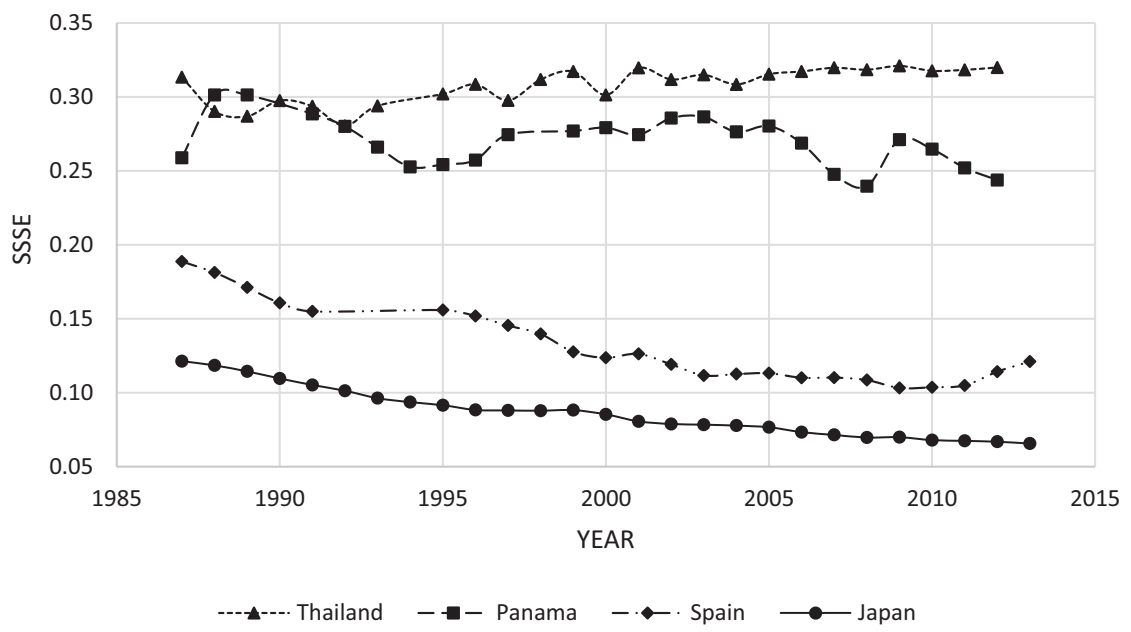

FIG. 2. Time Evol ution of Shar es of Empl oyer s and of Sol o Sel $\mathrm{f}$-empl oyed for Sel ected Countries, from Low First Quartile to High Fourth Quartile of GDPpc.

Notes: GDPpc in Year 2011 Constant \$ and PPP 2005: Thailand 3,158.07, Panama 6,694.08, Spain 25,240.85 and Japan 36,203.43.

Figure 2 shows the time evolution of $S E(2 \mathrm{a})$ and $S S E(2 \mathrm{~b})$ for four countries, one from each quartile of per-capita income: Thailand, Panama, Spain and Japan. Countries with large differences in per-capita income, e.g. Japan and Thailand, have relatively similar shares of employers, but very different shares of solo self-employed. Japan is the only country where the 


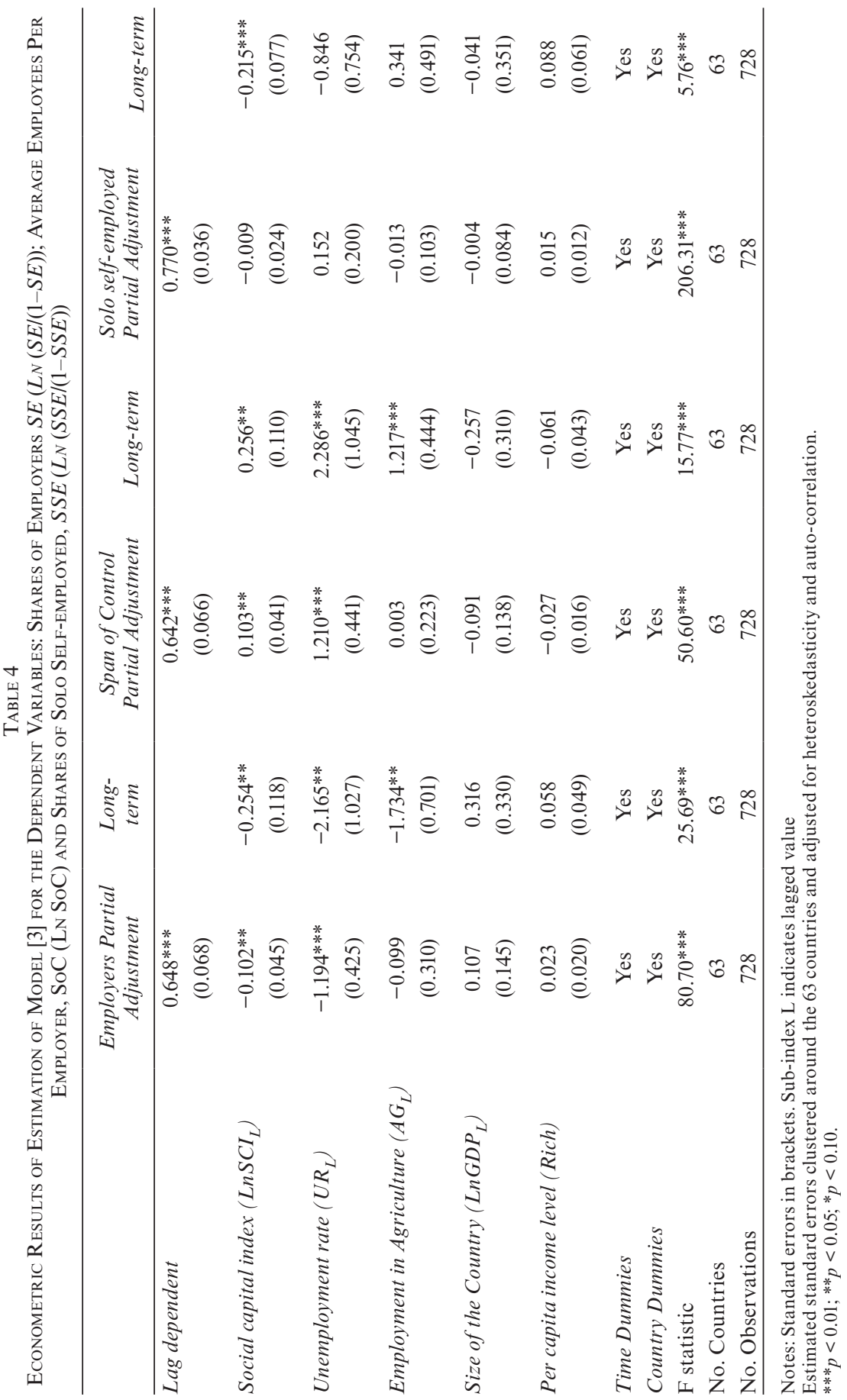

(C) 2018 The University of Manchester and John Wiley \& Sons Ltd 
shares of employers and of solo self-employed show a decreasing trend over time. In Spain, the share of solo self-employed decreases over time, but the share of employers has been stable for the last twenty years. In the lessdeveloped countries of Thailand and Panama, both the share of employers and the share of solo self-employed remain quite stable over time.

\subsection{Results of Estimating the Regression Models}

We now show, in Table 4, the results of the estimation of model [3] on the determinants of self-employment rates, separately for employers $(S E)$ and solo self-employed ( $S S E$ ), as well as that on the determinants of the average span of control $(\mathrm{SoC})$. For each dependent variable, we estimate two equations. The first, with the lagged dependent variable as explanatory, shortterm model, assumes that the observed values of the respective dependent variable are transition values that adjust over time towards a conditional desired equilibrium value. The second, without the lagged dependent variable, long-term model, considers that the observed values of the dependent variable are equilibrium values.

The estimated coefficient of the lagged dependent variable is relatively high and statistically significant in all estimations, indicating that the adjustment process towards the equilibrium is relatively slow, i.e. all the dependent variables show high persistence over time. In particular, the estimated time to convergence from the current to the desired value of dependent variables Share of Employers $(S E)$ and average Span of Control $(S o C)$ are approximately three years $(1 / \delta=1 /(1-0.64))$; while it is approximately four years $(1 / \delta=1 /(1-0.77))$ for the Share of Solo Self-employed (SSE).

As expected from the theory, the estimated coefficient of the Social Capital Index $(S C I)$, in the equation of determinants of the rate of employers (first two columns of Table 4), is negative and statistically significant. The empirical evidence confirms that higher levels of social capital imply lower relative numbers of employers among all occupied individuals, as predicted in Section 2. When the dependent variable is the average span of control $(\mathrm{SoC})$, the estimated coefficients for the $S C I$ practically equal those estimated when the dependent variable is the rate of employers but with opposite sign (two central columns of Table 4). The reason why the information in the dependent variable $S E$ can be different from the information in the variable $S o C$ is that in the calculation of the share of employers intervenes the number of solo self-employed while in the latter the solo self-employed do not intervene. Then, the equality in absolute values of the estimated coefficients for the two dependent variables indicates that cross-country differences and time evolution of solo self-employment rates have minor influence in the equilibrium rates of employers and employees. This would be consistent with the hypothesis that, in most of the countries 
in the database, the largest differences in the self-employed rates occur in the group of involuntary solo self-employed.

From the partial adjustment model of the employers' share, the estimated coefficient for the variable $S C I$ in the long-term equation is $-0.104 /$ $(1-0.647)=-0.249$, very close to that estimated directly in the long-term equation of -0.254 . Therefore, the two estimations are mutually consistent. The same happens with the estimated values of the coefficients of the respective variables in the model of span of control.

The last two columns of Table 4 show the estimated coefficients of the explanatory variables when the dependent variable is the share of solo self-employed. The time persistence of the values of the dependent variable is now even higher than with the previous two dependent variables (estimated coefficient of the lagged dependent variable equal to 0.77 ). In the partial adjustment model, none of the estimated coefficients of the other explanatory variables, including $S C I$, is statistically significant. However, in the long-term equilibrium equation, the estimated coefficient of the $S C I$ is negative and statistically significant.

Results are now different in the short- and long-term specifications, suggesting that the over-time high persistence in solo self-employed shares impedes the finding of any significant short-term effect of the explanatory variables. The estimated fixed effects capture the cross-section and permanent differences in shares across countries. In the long run, differences in $S C I$ do indeed imply differences in the equilibrium rates of solo self-employed. The negative estimated coefficient of the $S C I$ variable in the rate of solo self-employed equation is consistent with the prediction from Section 2 (theory), that lower organizational size diseconomies imply lower voluntary solo self-employment rates in the occupational choice equilibrium.

As for the estimated coefficients of the control variables, our results show that the shares of employers (the average span of control) are inversely (directly) related to unemployment rates and to the relative size of employment in agriculture. Therefore, in the long-term, the equilibrium average span of control is higher in countries with a higher structural unemployment rate, and a higher proportion of individuals working in agriculture. Controlling for the idiosyncratic differences (fixed effects) of countries, the long-term span of control-average productivity of entrepreneurs, is higher in countries with a high proportion of individuals working in agriculture (a proxy for economic backwardness). ${ }^{5}$ This result suggests that, in less-

\footnotetext{
${ }^{5}$ Notice from Table 2, of simple correlations among the variables, that the proportion of individuals occupied in agriculture is negatively correlated with the Rich dummy, and positively with solo self-employed rates. The non-statistically significant coefficient of the variable $A G$ in the solo self-employed equations suggests that there are idiosyncratic country-specific factors that jointly determine the employment in agriculture, the level of economic development, and the rates of solo self-employed. These idiosyncratic factors are not taken into account in calculating the simple correlations.
} 
developed countries, economic activity is polarized into two extremes, one with a relatively small number of large firms, and the other with small firms, mainly family ones, concentrated in agricultural activities (Hsieh and Olken, 2014). Notice also that the coefficient of the unemployment rate variable is not statistically significant in the estimation of the share of solo self-employed. Therefore, there is no supportive evidence that solo selfemployment is an occupation alternative for those people that do not find a job as employees.

Finally, we present some evidence on the economic relevance of the results. To shorten the exposition we focus only in the sensitivity of the span of control $(S o C)$ variable to changes in the social capital $(S C I)$, notice that the results with the variable $S E$ would be similar although of opposite sign. Both variables, the span of control and the social capital, are expressed in logs. Then, the estimated coefficient of the social capital variable in Table 4 is the elasticity of average span of control to social capital. In particular, the long term estimated elasticity of span of control of employers with respect to social capital is 25 per cent.

Thus, we can compare the average productivity of employers (average span of control) in a country with average social capital differing one standard deviation above of the sample mean. From Table 2, the sample mean of the $S C I$ is 0.95 and the standard deviation is 0.38 . Therefore, the country with social capital index one standard deviation above the mean will have a social capital index 40 per cent higher than that of the country in the sample mean $(0.38 / 0.95=0.4)$. As the elasticity of span of control to social capital is 25 per cent, the country with social capital one standard deviation above the mean will have an average span of control 10 per cent higher ( 25 per cent $\times 0.4=10$ per cent). We can also make across country comparisons using observed differences in social capital indexes. For example, the sample average of social capital index in Finland (1.5) doubles the Portugal's sample average (0.75), therefore the expected average productivity of employers (span of control) in Finland will be 25 per cent higher than the average productivity of employers in Portugal $(0.25 \times(1.5-0.75) / 0.75=25$ per cent).

\subsection{Robustness}

The robustness analysis has two parts. First, we estimate the models in Table 4 for different sets of explanatory variables and for separate sub-sample of countries. Second, we present results on determinants of self-employment rates and span of control with different measures of social capital-trust.

Since the IVIE social capital index is a compound value in whose calculation intervene several macroeconomic variables, there could be some redundancy between the $S C I$ variable and variables such as the unemployment rate, the proportion of agricultural workers or the level of country 
wealth. To examine if these possible redundancies could affect the results of the estimations we have re-estimated the models in Table 4 with only social capital, and dummies of time and country fixed effects as explanatory variables. The estimated coefficient of the social capital variable in all the specifications tends to be smaller than the coefficient shown in Table 4. Therefore, the sensitivity of the dependent variables to changes in the social capital variable is higher when all control variables are included among the explanatory variables of the empirical model, as in Table 4, than when they are excluded.

We have estimated the empirical model with data from countries with per capita income less or equal to the median of the sample (223 observations and 32 different countries). When the dependent variables are the share of employers and the span of control, the estimated coefficient of the lagged dependent variable is smaller than the one reported in Table 4 (close to 0.5). However, when the dependent variable is the share of solo selfemployed then the estimated coefficient of the lagged dependent variable is similar to that for the whole data sample in Table 4. Therefore, both endogenous variables share of employers and the span of control adjust towards the desired values at a comparatively higher speed in low per capita income countries.

In this sub-sample, when the dependent variable is the span of control, the estimated coefficients of the social capital are $0.11(p=0.046)$ in the partial adjustment and $0.13(p=0.2)$ in the long-term estimations. It seems that, in the partial adjustment model, countries with low income per capita present an estimated coefficient of the social capital similar to the whole sample (Table 4). However, in the long-term regression model, the elasticity of average span of control to social capital appears to be smaller in countries with low income per capita than in the whole sample (Table 4). The conclusion is similar when the dependent variable is the share of employers. It can be that, the target values of the dependent variables average span of control and share of employers show more volatility in low-income countries than in high-income ones.

\subsection{Results with Other Trust Variables}

One key issue in empirical studies of trust, social capital and economic performance is the measure of trust and social capital used in the analysis. In this section, we present an alternative empirical analysis of the relationship between level of trust, and country rates and productivity of employers (span of control), with measures of trust different from the IVIE social capital index. We have collected cross-country data on generalized trust for countries in the sample from the World Values Survey (21 countries) database (WVS, 2014) and the European Social Survey (24 countries) database (ESS, 2014). Data are available for intermittent years since 1999. The 
measure of trust from the WVS is the proportion of individuals who respond yes to the question of whether they generally trust others, while in the ESS the level of generalized trust is measured on a scale from 0 (low trust) to 10 (high trust). In order to obtain a homogeneous measure, and pool all countries in a single group, we standardize the values of the trust variables in the two sources (difference to the sample mean of the respective country value of the variable, divided by the standard deviation).

The trust values for each country from these surveys are very persistent and are available only for a small number of years. For this reason, we change the empirical analysis as follows. First, we estimate model [3] excluding $S C I$ variable, for each of the three endogenous variables ( $S E, S o C$ and $S S E$ ). The estimated country fixed effects in each of the three models are the long-term estimated equilibrium values of rates of employers, of average span of control and of rate of solo self-employed, respectively, when the countries' differences in social capital and trust are ignored. Next, we formulate and estimate three empirical models. The dependent variables are, respectively, the countries' estimated fixed effects in the modified empirical model [3] for the rates of employers, span of control and rates of solo self-employed. The explanatory variable in the three models is the mean value of the standardized trust variable of the corresponding country in the years from 1999 to 2011.

Table 5 presents the results of the estimated cross-section regression models. It shows two estimations, one with the pool of all 55 countries (All), and the other with a sub-sample of 24 European countries for which we have the responses from the ESS, i.e. the countries with a homogeneous measure of the trust variable. When the rate of employers and average span of control are the dependent variables, the estimated coefficients of the trust variable are statistically significant and have the same sign as those of the estimated coefficient for $S C I$ in Table 4. The estimated coefficient and its statistical significance are higher in the sub-sample of countries (ESS), perhaps because the trust measure is now homogeneous across countries. When solo self-employed is the dependent variable, the estimated coefficient of the trust variable is not statistically significant. This lack of significance brings into question the robustness of the results in Table 4, where, in the long term, the rate of solo self-employed is negatively correlated with social capital. In any case, the empirical results highlight once again the importance 


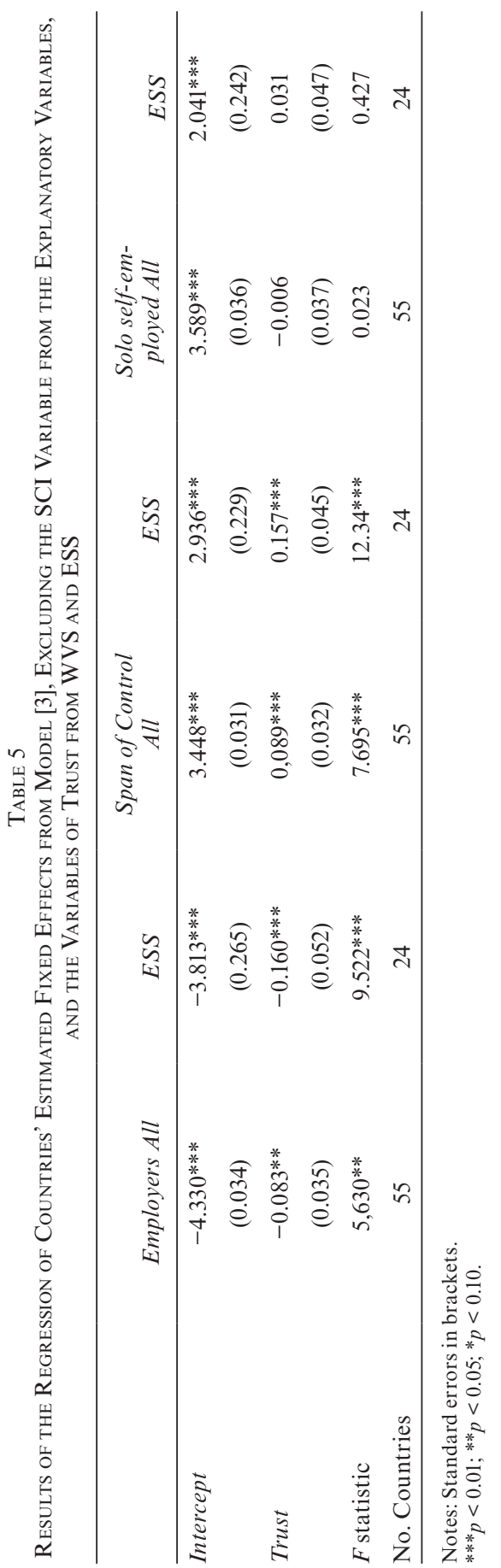

(C) 2018 The University of Manchester and John Wiley \& Sons Ltd 
of separating the solo self-employed from entrepreneurs-employers when explaining differences in self-employment rates among countries. ${ }^{6}$

\section{Conclusion}

Entrepreneurship as self-employment shows ambiguous results when correlated with economic development: total self-employment is proportionately higher in less-developed countries than in more developed ones, but the rate of employers, self-employed who hire employees, appears uncorrelated with the per capita income of countries. Evidence of this kind has led to the conclusion that not all entrepreneurs contribute equally to economic development (Lerner and Schoar, 2010). This paper acknowledges the importance of distinguishing between heterogeneous entrepreneurs, solo self-employed and employers, but it focuses on the previous question of why countries differ in entrepreneurship as synonymous of self-employment. If rates and composition of self-employed are endogenously determined then, from a policy point of view, the relevant questions are what conditions favour the kind of entrepreneurship that has a higher positive impact on economic development, and through what mechanisms.

The view of entrepreneurs in the occupational choice models is closer to the Coasian entrepreneur, the entrepreneur as an alternative to the price system for the direction of resources, than to the Schumpeterian entrepreneur, the entrepreneur as the main actor of innovation and creative destruction. In the Coasian's world, there are transaction costs that explain why certain transactions take place in markets and why some transactions take place within firms. Arrow's (1974) view of trust as a 'lubricant' of the economy can be interpreted as considering trust a social institution that can save in transaction costs and ultimately increase overall economic efficiency. However, little is known on whether social capital contributes to economic efficiency equally as lubricant of market-mediated transactions than as lubricant of entrepreneurs-mediated transactions. If trust lowers the transaction costs of markets and firms in similar amounts then differences in trusts across countries would had no effect in the respective distribution of firm sizes. However, the evidence in this paper shows that trust is positively correlated with the average productivity of entrepreneurs (larger average span of control of employers and fewer entrepreneurs in countries with higher

${ }^{6}$ Additional robustness analyses of the results of Table 4 include different ways of calculating the values of the dependent variable. First, the share of employers is calculated as employers over the economically active population (total employment plus unemployment). This definition of the variable would be consistent with the hypothesis that unemployment is an additional occupational choice, voluntary or involuntary. We have estimated the first two columns of Table 4 with the new definition of the dependent variable and our main results remain unchanged (results available upon request). The second variation consists in substituting the logistic transformation of the dependent variable employers' share $(S E)$ by its logarithm. Once again, all results and conclusions remain unchanged. 
trust), suggesting that trust favours more firm mediated than market mediated transactions.

The explanation from the occupational choice theory of this result is that higher trust facilitates the adoption by entrepreneurs of organizational designs in their firms with higher delegation of decision making in lower levels of the hierarchy. The efficient delegation saves in intensity of supervision in the execution of the entrepreneurial decisions and entrepreneurs are in a better position to take advantage of the scale economies in skills in terms of quality of the decisions: better entrepreneurial decisions by more skilled entrepreneurs leverage the productivity of all resources under their direction, including the employees. In the market equilibrium with higher trust and more delegation the hierarchical control of employees by the employers is less intense, entrepreneurs of given skills can efficiently direct more resources and, ultimately, the market equilibrium involves fewer and more productive entrepreneurs (fewer firms and more transactions within firms and less between firms).

In entrepreneur-mediated transactions, higher quality of the entrepreneurial decisions creates externalities in the form of increasing the productivity of resources under the direction of the entrepreneur that do not happen in market mediated transactions. Management costs, the name that Coase uses to refer to the transaction costs of using the entrepreneur-firm in governing transactions, limit the growth of firms and explain why not all people work under the direction of the more skilled entrepreneur. In societies with higher levels of trust, entrepreneurs adopt more decentralized organization designs that lower management costs and simultaneously reduce the organizational size diseconomies and the internal costs of growth. This means that with higher trust, resources are relocated from smaller to larger firms under the direction of the more skilled entrepreneurs so more people benefit (leverage their productivity) from the scale economies of entrepreneurial skills considered in occupational choice models.

Traditional occupational choice models do not consider the solo self-employed as a third alternative occupational choice additional to employees and employers. The theoretical predictions on how higher level of generalized trust will affect the equilibrium number of solo self-employed in the occupational choice equilibrium are not as robust as the predictions on the productivity of entrepreneurs-employers (Medrano-Adán et al., 2015). Since the solo self-employed individuals do not hire employees, there are no scale economies effects from the quality of their entrepreneurial decisions. The empirical evidence presented in this paper shows some contradictory results: in the short run, solo self-employment rates appear independent of the level of generalized trust of countries, while in the long term the association is negative and statistically significant. In the sub-sample of lowincome countries, the share of solo self-employed appears independent of the social capital index. This and other evidences suggests that the influence 
of differences in social capital in the way production is organized in less developed countries is not so robust as it appears to be in more developed ones. This could be consistent with the finding of Gur and Bjornskov (2017) that the association between trust and delegation is weaker in lessdeveloped countries than in more developed ones. In any case, further research is needed to find out whether the effect of trust on the comparative transaction costs of market and firm mediated transactions is sensible or not to the level of economic development of the countries.

Finally, the benefits from more delegation and less hierarchical supervision in environments of generalized trust may go beyond those attributed to the higher productivity of entrepreneurs following from the scale economies of skills in the decision-making function of entrepreneurs. It has been documented that the adoption and use of information and communications technologies contributes more to productivity in decentralized organizations than in centralized ones (Brynjolfsson et al., 1994; Bresnahan et al., 2002; Rajan and Wulf, 2006; Bloom et al., 2012). Globalization increases the competition among firms located in distant countries and regions; firms located in countries and regions endowed with low social capital will be at a competitive disadvantage with respect to those operating in environments of high social capital, because the latter will be able to jointly implement a decentralization of decision power and more intensive use of ICT.

\section{Appendix: The IVIE Index of Social Capital}

The IVIE index of social capital is based on the idea that reciprocity, the cultural rule of 'tit for tat', justifies investing in reputation and, once reputation is build, it can be used as collateral in tacit agreements that govern economic transactions. People need assurances about what the behaviour of transaction partners will be under certain circumstances. The common instrument to protect from hazardous behaviour in transactions is the contract. Contracts can be explicit and complete, and implicit and incomplete. In general, information asymmetries make explicitcomplete contract more expensive in terms of transaction costs than the implicitincomplete ones. For this reason, societies that can rely more generally on implicit contracts to govern transactions will be more prosperous than otherwise because their economic system will function with lower transaction costs. The view of trust as lubricant of the economic system, Arrow (1974), means that, when trust is generalized, collaboration and exchange takes place more under self-fulfilling mutual promises and cooperative behaviour, and less under the threat of denounces in courts.

Economists have formalized this idea with modelling the so-called 'trust game with repetition and uncertain end play' (Kreps, 1990). The best social outcome of the posed transaction situation requires one party be trustworthy to the other and that means convincing to the party whose trust is demanded (accepting her promise that will honour the trust) that it is in the best interest to honour the promise than to abuse it. The trade-offs that the party appearing trustworthy must manage include a short-term gain of abusing on the one hand, and the present value of 
expected gains from future repeated transactions that, from the reciprocity rule, will be lost from the moment that there is an abuse and the trusted person collects the short-term gain. When a trustee honours the promise the short-term gain she renounces to is the cost of investing in reputation; in exchange, the trustee holds the expectation of renewing the trustworthiness in future profitable transactions so the net present value of the investment is positive.

What the developers of the IVIE index of social capital do, following Glaeser et al. (2002), is to operationalize the calculation of the pay-offs of the trust game and determine the investment in reputation that is optimal for a representative individual in every moment in time, i.e. it maximizes the economic value of the resulting stock of social capital. Next, they aggregate the individual social capital into a collective measure of social capital in the form of one public good whose benefits for everyone are in the form of saving in transaction costs from participating in production and exchange activities. The collective capital stock is equal to the product of the social capital of the representative individual times the opportunities to participate in transactions that this individual has in one to one basis (its personal network of relations), and times the number of potential people with whom the person interacts. The contribution of the IVIE research team is in identifying a set of observable socio-economic variables that can be used to calculate the individual and the collective stock of social capital services. The social capital is an asset (it has economic value) with economic life of more than a year that varies over time with the net difference between the new investments flows and the economic depreciation of the stock, as it happens with other tangible assets of the economy.

In the original methodological paper (Pérez García et al., 2006), the analytical formalization of the individual investment problem and the aggregation to get the social capital of the economy-territory as a public good that facilitates the use of implicit contracts in transactions are summarized in two equations, the first order condition of the optimal individual investment, and the aggregation to the stock of capital services of the economy (public good):

$$
\begin{gathered}
k s_{t}^{*}=\beta\left[\frac{1+\lambda(N-1)}{N}\right] \frac{y_{t}}{\bar{w}_{t} C^{\prime}\left(I s_{t}^{*}\right)}(1-G) \frac{1-\left(\frac{\delta}{1+\rho}\right)^{T-t}}{1+\rho-\delta} \\
K S_{t}^{*}=N_{t} c s k_{t}^{*}
\end{gathered}
$$

where $k s^{*}{ }_{t}$ is the capital stock of the representative individual of the economy in period $t$ and $I s_{t}^{*}$ is the optimal investment flow in this capital in period $t$ by the representative person. $\beta$ is the elasticity of output to the stock of social capital of the economy (estimated empirically from the production function of the economy). $\lambda$ is the measure of how installed is the reciprocity rule in the economy, assumed to be one. $N_{t}$ is the number of persons working in the economy. $y_{t}$ is the GDP of the economy. $w_{t}$ is the opportunity cost per unit of time spend in investing in social capital approximated by the average wage per employee of the economy. $C^{\prime}\left(I s_{t}^{*}\right)$ is the marginal cost of the investment in social capital, proxied inversely by the share of population with at least secondary education. $I s_{t}^{*}$ is the optimal investment flow (C) 2018 The University of Manchester and John Wiley \& Sons Ltd 
in this capital in period $t$ by the representative person. $G$ is the risk of getting excluded from participating in economic exchanges, measured by the GINI coefficient of income inequality. $\rho$ is the real interest rate of the economy (time discount rate) assumed equal to 4 per cent. $\delta$ is one minus the depreciation rate of the social capital (inversely related to the unemployment rate). $T$ is the life expectancy of the economy. $c$ is the degree of interconnectedness of the representative person in the economy (measured by the ratio of bank loans over the GDP of the economy).

The stock of social capital used in this paper is an aggregate for the whole economy calculated from the expressions above with the listed proxy variables and normalized to the value of one in year 2000. The stock is referred to end of the year and is available for different number of years depending on the country (incomplete panel data).

\section{REFERENCES}

Acs, Z., Audretsch, D. and Evans, D. (1994) Why Does the Self-employment Rate Vary Across Countries and Over Time? London: Center for Economic Policy Research, CERP D.P. No. 871.

Adler, P. and Kwon, S.W. (2002) Social capital: prospects for a new concept. Academy of Management Review, 27(1), 17-40.

Aghion, P. and Tirole, J. (1997) Formal and real authority. Journal of Political Economy, 105(1), 1-29.

Aghion, P., Bloom, N. and Van Reenen, J. (2014) Incomplete contracts and the internal organization of firms. Journal of Law, Economics and Organization, 30(1), i37-i63.

Akçomak, I.S. and ter Weel, B. (2009) Social capital, innovation and growth: evidence from Europe. European Economic Review, 53(5), 544-567.

Alesina, A. and La Ferrara, E. (2002) Who trusts others. Journal of Public Economics, 85(2), 207-234.

Alexy, O.T., Block, J.H., Sandner, P. and Ter Wal, A. (2012) Social capital of venture capitalists and start-up funding. Small Business Economics, 39(4), 835-851.

Arrow, K. (1974) The Limits of Organization. New York: Norton.

Audretsch, D.B., Keilbach, M. and Lehmann, E. (2006) Entrepreneurship and Economic Growth. New York: Oxford University Press.

Bahmani, S., Galindo, M.A. and Méndez, M.T. (2012) Non-profit organizations, entrepreneurship, social capital and economic growth. Small Business Economics, 38(3), 271-281.

Baron, S., Field, J. and Schuller, T. (Eds.) (2010) Social Capital: Critical Perspectives. Oxford: Oxford University Press.

Bento, P. and Restuccia, D. (2015) Misallocation, establishment size and productivity. American Economic Journal: Macroeconomics, 9(3), 267-303.

Blanchflower, D. (2000) Self-employment in OCDE countries. Labour Economics, 7(5), 471-505.

Blau, D.M. (1987) A time-series analysis of self-employment in the United States. Journal of Political Economy, 95(3), 445-467.

Bloom, N., Sadun, R. and Van Reenen, J. (2012) The organization of firms across countries. Quarterly Journal of Economics, 127(4), 1663-1705.

Bosma, N., van Praag, M., Thurik, R. and de Wit, G. (2004) The value of human and social capital investments for the business performance of startups. Small Business Economics, 23(3), 227-236. 
Bourdieu, P. (1980) Le Capital Social: Notes Provisories. Actes de la Recherche en Sciences Sociales, 31, Janvier, 2-3.

Bramoullé, Y. and Kranton, R. (2007) Public goods in networks. Journal of Economic Theory, 135(1), 478-494.

Bresnahan, T., Brynjolfsson, E. and Hitt, L.M. (2002) Information technology, workplace organization, and the demand for skilled labor: firm-level evidence. Quarterly Journal of Economics, 117(1), 339-376.

Brynjolfsson, E., Malone, T., Gurbaxani, V. and Kambil, A. (1994) Does information technology lead to smaller firms. Management Science, 40(12), 1628-1645.

Burt, R. (1982) Toward a Structural Theory of Action. New York: Academic Press.

Carree, M. and Thurik, R. (2008) The lag structure of the impact of business ownership on economic performance in OECD countries. Small Business Economics, 30(1), 101-110.

Cingano, F. and Pinotti, P. (2016) Trust, firm organization and the pattern of comparative advantage. Journal of International Economics, May, 100, 1-13.

Coase, R. (1937) The nature of the firm. Economica, 4(16), 386-405.

Coleman, J.S. (1988) Social capital in the creation of human capital. American Journal of Sociology, 94(Supplement), S95-S120.

Coleman, J.S. (1990) Foundations of social theory. Cambridge, MA: Harvard University Press.

ESS. (2014) European Social Survey. Data are available for download and online analysis at: https://www.europeansocialsurvey.org [Downloaded July 2014].

Estrin, S., Mickiewicz, T. and Stephan, U. (2013) Entrepreneurship, social capital, and institutions: social and commercial entrepreneurship across nations. Entrepreneurship Theory and Practice, 37(3), 479-504.

Evans, D.S. and Leighton, L.S. (1989) Some empirical aspects of entrepreneurship. The American Economic Review, 79(3), 519-535.

Fernández de Guevara, J., Pérez, F. and Serrano, L. (2015) Crisis económica, confianza y capital social. Bilbao España: Fundación BBVA.

Fritsch, M. and Storey, D.J. (2014) Entrepreneurship in a regional context: historical roots, recent developments and future challenges. Regional Studies, 48(6), 939-954.

Fritsch, M., Kritikos, A. and Sorgner, A. (2015) Why did self-employment increase so strongly in Germany? Entrepreneurship and Regional Development, 27(5-6), 307-333.

Garicano, L. (2000) Hierarchies and the organization of knowledge in production. Journal of Political Economy, 108(5), 874-904.

Garicano, L. and Rossi-Hansberg, E. (2006) Organization and inequality in a knowledge economy. Quarterly Journal of Economics, 121(4), 1383-1435.

Gedajlovic, E., Honig, B., Moore, C.B., Payne, G.T. and Wright, M. (2013) Social capital and entrepreneurship: a schema and research agenda. Entrepreneurship Theory and Practice, 37(3), 455-478.

Gindling, T. and Newhouse, D. (2014) Self-employment in the developing world. World Development, April, 56, 313-331.

Glaeser, E.L., Laibson, D. and Sacerdote, B. (2002) An economic approach to social capital. The Economic Journal, 112(483), F437-F458.

Gollin, D. (2008) Nobody's business but my own: self-employment and small enterprise in economic development. Journal of Monetary Economics, 55(2), 219-233.

Guiso, L., Sapienza, P. and Zingales, L. (2004) The role of social capital in financial development. American Economic Review, 94(3), 526-554.

Gur, N. and Bjornskov, C. (2017) Trust and delegation: theory and evidence. Journal of Comparative Economics, 45(3), 644-657. 
Hopenhayn, H. (2016) Firm size and development. Economia, Journal of the Latin American and Caribbean Economic Association, 17(1), 27-49.

Hsieh, C. and Olken, B. (2014) The missing 'Missing Middle'. Journal of Economic Perspectives, 28(3), 89-108.

ILOSTAT. (2013) ILOSTAT Database. Geneva: International Labour Office (ILO). Available at: https://www.ilo.org/ilostat.

Knack, S. and Keefer, P. (1997) Does social capital have an economic pay-off? A cross-country investigation. Quarterly Journal of Economics, 112(4), 1251-1288.

Kreps, D. (1990) Corporate culture and economic theory. In: Alt, J. and Shepsle, K. (Eds.) Perspectives on Positive Political Economy. Cambridge, England: Cambridge University Press, pp. 90-142.

Kummar, K., Rajan, R. and Zingales, L. (2002) What Determines Firms Size? Chicago GSB: The University of Chicago Booth School of Business. Available at: https://faculty.chicagobooth.edu/raghuram.rajan/research/papers/size.pdf.

Kuznets, S. (1966) Modern Economic Growth. New Haven, CT: Yale University Press.

Kwon, S.-K. and Adler, P.S. (2014) Social capital: maturation of a field of research. Academy of Management Review, 39(4), 412-422.

Kwon, S.-K. and Arenius, P. (2010) Nations of entrepreneurs: a social capital perspective. Journal of Business Venturing, 25(3), 315-330.

La Porta, R., López de Silanes, F., Shleifer, A. and Vishny, R. (1997) Trust in large organizations. American Economic Review Papers and Proceedings, 87(2), $333-338$.

Lerner, J. and Schoar, A. (Eds.) (2010) International Differences in Entrepreneurship, National Bureau of Economic Research. Chicago, IL: University of Chicago Press.

Lucas, R. (1978) On the size distribution of firms. The Bell Journal of Economics, $9(2), 508-523$.

McKeever, E., Anderson, A. and Jack, S. (2014) Entrepreneurship and mutuality: social capital in processes and practices. Entrepreneurship and Regional Development, 26(5-6), 453-447.

Medrano-Adán, L., Salas-Fumás, V. and Sanchez-Asin, J.J. (2015) Heterogeneous entrepreneurs from occupational choices in economies with minimum wages. Small Business Economics, 43(3), 597-619.

Michelacci, C. and Silva, O. (2007) Why so many local entrepreneurs? The Review of Economics and Statistics, 89(4), 615-633.

Miguélez, E., Moreno, R. and Artis, M. (2011) Does social capital reinforce technological inputs in the creation of knowledge? Evidence from the Spanish regions. Regional Studies, 45(8), 1019-1038.

Naudé, W. (2013) Entrepreneurship and Economic Development: Theory, Evidence and Policy, IZA DP No. 7507, IZA, Institute Institute of Labor Economics.

OECD. (2016) OECD Factbook 2015-2016: Economic, Environmental and Social Statistics. Paris: OECD Publishing. doi:https://doi.org/10.1787/ factbook-2015-en.

Pastor, J.M. and Tortosa-Ausina, E. (2008) Social capital and bank performance: an international comparison for OECD countries. The Manchester School, 76(2), 223-265.

Peiró-Palomino, J. and Tortosa-Ausina, E. (2015) Social capital, investment and economic growth. Spatial Economic Analysis, 10(1), 102-126.

Pérez García, F., Montesinos, V., Serrano, L. and Fernández de Guevara, J. (2006) Measurement of Social Capital and Growth: An Economic Methodology. 
Working Paper, 4. Bilbao, ES: Fundación BBVA. Available at: https://w3.grupobbva.com/TLFU/dat/DT_2006_04.pdf.

Putnam, R. (1995) Bowling alone. America's declining social capital. Journal of Democracy, 6(1), 65-78.

Rajan, R. and Wulf, J. (2006) The flattening firm: evidence from panel data on the changing nature of corporate hierarchies. The Review of Economics and Statistics, 88(4), 759-773.

Rosen, S. (1982) Authority, control, and the distribution of earnings. The Bell Journal of Economics, 13(2), 311-323.

Salas-Fumás, V. and Sanchez-Asin, J.J. (2013a) Entrepreneurial dynamics of the self-employed and of firms: a comparison of determinants using Spanish data. International Entrepreneurship and Management Journal, 9(3), 417-446.

Salas-Fumás, V. and Sanchez-Asin, J.J. (2013b) Information and trust in hierarchies. Decision Support Systems, 55(4), 988-999.

Salas-Fumás, V., Sanchez-Asin, J.J. and Storey, D. (2014) Occupational choice, number of entrepreneurs and output: theory and evidence with Spanish data. SERIEs-Journal of the Spanish Economic Association, 5(1), 1-24.

Wennekers, S., vanStel, A., Carree, M. and Thurik, R. (2010) The relationship between entrepreneurship and economic development: is it U-shaped? Foundations and Trends ${ }^{\circledR}$ in Entrepreneurship, 6, 167-231.

Westlund, H. and Adam, F. (2010) Social capital and economic performance: a meta-analysis of 65 studies. European Planning Studies, 18(6), 893-919.

Westlund, H. and Bolton, R. (2003) Local social capital and entrepreneurship. Small Business Economics, 21(2), 77-113.

Westlund, H., Larsson, J.P. and Olsson, A.R. (2014) Start-ups and local entrepreneurial social capital in the municipalities of Sweden. Regional Studies, 48(6), 974-994.

Williamson, O. (1993) Calculative trust and economic organization. Journal of Law and Economics, 36(1), Apr. part, 2, 453-486.

WVS (2014) World Value Survey 1981-2014 Official Aggregate v.20140617, 2014. World Values Survey Association. Available at: www.worldvaluessurvey.org.

Zak, P. and Knack, S. (2001) Trust and Growth. The Economic Journal, 111(443), 295-321. 